\title{
Efektivitas Ekshumasi dalam Pengungkapan Kasus di Bagian Ilmu Forensik dan Medikolegal FK Unsrat RSUP Prof. Dr. R. D. Kandou Tahun 2015-2016
}

\author{
${ }^{1}$ Gracia Lolong \\ ${ }^{2}$ Nola T. S. Mallo \\ ${ }^{2}$ Johannis F. Mallo \\ ${ }^{1}$ Kandidat Skripsi Fakultas Kedokteran Universitas Sam Ratulangi Manado \\ ${ }^{2}$ Bagian Ilmu Forensik dan Medikolegal Fakultas Kedokteran \\ Universitas Sam Ratulangi Manado \\ Email: gracialolong29@yahoo.co.id
}

\begin{abstract}
Exhumations should be conducted when a death is suspected unnatural. Recently, exhumations are particularly conducted in foreign countries when they have problems related to health insurance, meanwhile, in Indonesia, exhumation cases are more often asked by the families through the police due to unnatural deaths. Through exhumation, many criminal cases have been revealed. This study was aimed to obtain the effectiveness of exhumations at the Forensic and Medicolegal Department Prof. Dr. R. D. Kandou Hospital Manado from 2015 through 2016. The results showed that there were 9 exhumations recorded at the Forensic and Medicolegal Department Prof. Dr. R. D. Kandou Hospital Manado during that period. The causes of deaths could be found out after exhumations. Conclusion: Exhumation could reveal effectively the causes of deaths in 2015-2016 at the Forensic and Medicolegal Department Prof. Dr. R. D. Kandou Hospital Manado.
\end{abstract}

Keywords: exhumation, florensic cases

\begin{abstract}
Abstrak: Kasus ekshumasi atau penggalian mayat perlu dilakukan ketika dicurigai kematian seseorang dianggap tidak wajar. Ekshumasi sekarang ini khususnya di luar negeri sering diminta ketika timbul masalah pada asuransi kesehatan daripada oleh keluarga. Di Indonesia, kasus ekshumasi lebih sering diminta oleh keluarga melalui kepolisian akibat penyebab kematian yang tidak wajar. Melalui ekshumasi telah banyak kasus kejahatan yang berhasil diungkapkan kebenarannya. Penelitian ini bertujuan untuk mengetahui efektifitas ekshumasi dalam pengungkapan kasus di Bagian Forensik RSUP Prof. Dr. R. D. Kandou Manado tahun 2015-2016. Hasil penelitian mendapatkan 9 kasus ekshumasi di Bagian Forensik RSUP Prof. Dr. R. D. Kandou Manado selama tahun 2015-2016. Penyebab kematian pada semua kasus ekshumasi dapat ditemukan. Simpulan: Ekshumasi efektif dalam mengungkapkan penyebab kematian pada semua kasus di Bagian Forensik RSUP Prof. Dr. R. D. Kandou Manado selama tahun 2015-2016.
\end{abstract}

Kata kunci: ekshumasi, kasus forensik

Ekshumasi adalah penggalian mayat atau pembongkaran kubur yang dilakukan demi keadilan oleh yang berwenang dan berkepentingan dan selanjutnya mayat tersebut diperiksa secara ilmu kedokteran forensik. ${ }^{1}$
Ekshumasi perlu dilakukan ketika dicurigai kematian seseorang dianggap tidak wajar. Di luar negeri, ekshumasi sekarang ini sering diminta ketika timbul masalah pada asuransi kesehatan. Beberapa kasus di luar negeri lebih banyak diminta 
oleh asuransi kesehatan daripada oleh keluarga. Pada prinsipnya, keluarga berhak menolak autopsi yang diminta oleh pihak asuransi, namun risiko yang harus dihadapi oleh keluarga ialah kehilangan seluruh klaim yang seharusnya mereka dapatkan sebagai konsekuensi asuransi. Dibandingkan autopsi yang segera dilakukan setelah kematian, ekshumasi membutuhkan lebih banyak biaya tambahan untuk penggalian kubur, transpor, pembersihan, biaya bagi pemeriksa medis, dan untuk penguburan kembali. Selain itu hasil pemeriksaan terhadap jenazah yang telah lama dikubur tidak akan memberikan hasil lebih baik bila dibandingkan dengan pemeriksaan pada jenazah yang masih baru. ${ }^{2,3}$

Batas waktu permintaan dilakukan ekshumasi di tiap-tiap negara berbedabeda. Di Perancis contohnya batas waktunya hanya sampai 10 tahun sedangkan di Jerman batas waktunya sampai 30 tahun. Bila penyidik dalam rangkaian penyidikannya memerlukan bantuan dokter untuk melakukan pemeriksaan terhadap jenazah yang telah dikubur maka seorang dokter wajib melaksanakan pemeriksaan tersebut. Oleh karena itu, dokter perlu memahami dengan benar peranannya dan pemeriksaan apa saja yang harus dilakukan terhadap jenazah yang telah dikubur sehingga dapat memberi keterangan yang bermanfaat untuk kepentingan peradilan saat dilaksanakan ekshumasi. $^{4,5}$

Melalui ekshumasi telah banyak kasuskasus kejahatan yang berhasil diungkapkan kebenarannya. Sebagai contoh yaitu kasus pelanggaran hak azazi manusia (HAM) yang dilakukan ekshumasi karena jenazahjenazah dikubur secara masal tanpa sepengetahuan orang lain di Tanjung Priok tahun 2000. Kasus ekshumasi lainnya pada tahun 2010 dilakukan pada jenazah balita di desa Karanganyar dan Pandegelang. Bahkan di Palestina, ekshumasi dilakukan tahun 2011 pada jenazah seorang mantan presiden Palestina. Pada tahun 2014 ekshumasi dilakukan terhadap jenazah pengusaha kilang padi di desa Pawoh, Kecamatan Susoh. ${ }^{6}$
Penelitian ini bertujuan untuk mendapatkan efektifitas ekshumasi dalam pengungkapan kasus di Bagian Ilmu Forensik dan Medikolegal FK Unsrat RSUP Prof. Dr. R. D. Kandou tahun 20152016.

\section{METODE PENELITIAN}

Jenis penelitian ialah deskriptif retrospektif menggunakan data yang diambil di Bagian Forensik dan Medikolegal RSUP Prof. Dr. R. D. Kandou Manado periode 2015-2016. Variabel penelitian ialah jumlah kasus dan sebab kematian.

\section{HASIL PENELITIAN:}

Berdasarkan data yang dikumpulkan dari bagian Forensik dan Medikolegal RSUP Prof. Dr. R. D. Kandou Manado didapatkan kasus ekshumasi yang dilakukan sepanjang tahun 2015-2016 sebanyak 9 kasus (Tabel 1). Berdasarkan data jenis kelamin, 8 dari 9 kasus ekshumasi pada jenazah laki-laki, sisanya ialah jenazah perempuan (Tabel 2).

Berdasarkan permintaan dari kepolisian daerah didapatkan yang terbanyak mengajukan permintaan ekshumasi ialah dari kepolisian daerah Gorontalo sebanyak 3 permintaan (Tabel 3).

Untuk efektifitas ekshumasi dalam mengungkapkan kasus kematian sepanjang tahun 2015-2016 sebanyak 9 kasus dan semuanya diketahui penyebab kematiannya setelah dilakukan ekshumasi (Tabel 4).

Tabel 1. Jumlah kasus ekshumasi

\begin{tabular}{cc}
\hline Jenis kelamin & Jumlah kasus \\
\hline Laki-Laki & 8 \\
Perempuan & 1 \\
Total & 9 \\
\hline
\end{tabular}

Tabel 2. Jumlah kasus ekshumasi dibagi berdasarkan jenis kelamin

\begin{tabular}{cc}
\hline Jenis kelamin & Jumlah kasus \\
\hline Laki-Laki & 8 \\
Perempuan & 1 \\
Total & 9 \\
\hline
\end{tabular}


Tabel 3. Jumlah kasus ekshumasi berdasarkan POLSEK permintaan

\begin{tabular}{ccc}
\hline No & POLSEK permintaan & Jumlah kasus \\
\hline 1 & Kepolisian Resor Minahasa & 1 \\
2 & Kepolisian Sektor Tomohon Utara & 1 \\
4 & Kepolisisan Resor Gorontalo & 3 \\
5 & Kepolisian Sektor Rural, Likupang & 1 \\
6 & Kepolisian Sektor Wanea & 1 \\
7 & Kepolisian Resor Minahasa Selatan & 2 \\
& Jumlah total & 9 \\
\hline
\end{tabular}

Tabel 4. Efektifitas ekshumasi dalam pengungkapan kasus berdasarkan sebab kematian

\begin{tabular}{|c|c|c|}
\hline Kode & $\begin{array}{l}\text { Sebab kematian } \\
\end{array}$ & Kasus terungkap \\
\hline A.1 & $\begin{array}{l}\text { Kekerasan tumpul pada daerah kepala kiri yang } \\
\text { mengakibatkan cedera orak }\end{array}$ & + \\
\hline B.2 & $\begin{array}{l}\text { Tenggelam atau masuknya cairan yang cukup } \\
\text { banyak ke dalam saluran nafas \& paru }\end{array}$ & + \\
\hline C. 3 & Peradangan akut kelenjar ludah perut & + \\
\hline D.4 & $\begin{array}{l}\text { Kekerasan tajam memotong jaringan otak besar kiri, } \\
\text { jaringan paru kiri, memotong putus pembuluh balik } \\
\text { dan pembuluh nadi leher kiri, jantung dan jaringan } \\
\text { hati }\end{array}$ & + \\
\hline E. 5 & $\begin{array}{l}\text { Luka bacok di puncak kepala yang masuk ke rongga } \\
\text { kepala dan merusak jaringan otak }\end{array}$ & + \\
\hline F.6 & $\begin{array}{l}\text { Kekerasan tumpul pada daerah dada kiri yang } \\
\text { mengakibatkan perdarahan pada otot bilik kiri } \\
\text { jantung }\end{array}$ & + \\
\hline G.7 & $\begin{array}{l}\text { Tergantung, terhalangnya saluran nafas bagian atas } \\
\text { sehingga mati lemas }\end{array}$ & + \\
\hline H.8 & $\begin{array}{l}\text { Tergantung, terhalangnya saluran nafas bagian atas } \\
\text { sehingga mati lemas }\end{array}$ & + \\
\hline I.9 & $\begin{array}{l}\text { - Kekerasan tumpul di daerah dada sehingga patah } \\
\text { tulang dada mengakibatkan kegagalan pernafasan } \\
\text { - Ada racun sianida dalam lambung }\end{array}$ & + \\
\hline
\end{tabular}

\section{BAHASAN}

Ekshumasi merupakan suatu tindakan medis yang dilakukan atas dasar undangundang dalam rangka pembuktian suatu tindakan pidana dengan menggali kembali jenazah. Prosedur yang dilakukan dalam ekshumasi ini pada prinsipnya harus dilakukan sesegera mungkin dan seteliti mungkin. Peranan dokter sangat penting dalam ekshumasi yaitu dokter, sebagai saksi ahli, harus hadir sejak penggalian kubur sampai melakukan pemeriksaan terhadap tubuh mayat yang diekshumasi dan menyimpulkan apa yang didapatkan dari pemeriksaan tersebut, dan jika memungkinkan mencari sebab kematian. ${ }^{7,8}$
Hasil yang diperoleh dari penelitian mengenai efektifitas ekshumasi dalam pengungkapan kasus di Bagian Ilmu Forensik dan Medikolegal FK Unsrat RSUP Prof. Dr. R. D. Kandou Manado mendapatkan sebanyak 9 kasus. Jumlah keseluruhan kasus ekshumasi pada Bagian Forensik dan Medikolegal FK Unsrat RSUP Prof. Dr. R. D. Kandou Manado pada tahun 2015 terdapat 4 kasus ekshumasi, sedangkan pada tahun 2016 terdapat 5 kasus ekshumasi. Jumlah lakilaki sebanyak 8 kasus sedangkan jumlah perempuan sebanyak 1 kasus.

Semua kasus ekshumasi dalam tahun 2015-2016 diketahui sebab kematiannya 
setelah dilakukan ekshumasi yang menunjukkan bahwa ekshumasi efektif dalam mengungkapkan sebab kematiann.

\section{SIMPULAN}

Dari hasil penelitian dapat disimpulkan bahwa ekshumasi efektif dalam mengungkapkan penyebab kematian pada semua kasus di Bagian Forensik RSUP Prof. Dr. R. D. Kandou Manado selama tahun 2015-2016.

\section{SARAN}

Disarankan pada penelitian selanjutnya untuk menambah variabel penelitian. Ekshumasi diharapkan menjadi topik yang secara khusus dibahas dalam ilmu kedokteran forensik agar para calon dokter mendapatkan gambaran mengenai peran ekshumasi dalam mengungkapkan penyebab kematian.

\section{DAFTAR PUSTAKA}

1. Mu'im IA. Pedoman Ilmu Kedokteran Forensik (1st ed). Jakarta: Binarupa
Askara, 1997; p. 323-7.

2. Kristanto S. Kedokteran Forensik. Manado, 1989; p. 59-63.

3. Sarajevo. Batajnica Summary Report Forensic Monitoring Activities. ICMP. 2004.

4. Claridge J. Exhuming a corpse for forensic analysis. Explore Forensic. 9 Agustus 2014. [cited 2016 Sept 4]. Available from:

http://www.exploreforensics.co.uk/exh uming-a-corpose-for-forensicanalysis.html.

5. Hoboken NJ. Ilmu Kedokteran Forensik (3rd ed). Jakarta: Dinas Kedokteran dan Kesehatan Polri, 1989; p. 73-6.

6. Makam Arafat akan dibongkar. 26 November 2012. [cited 2016 Aug 30]. Available from:

http://tekno.kompas.com/read/2012/11/ 26/05075559/makam.arafat.akan.dibon gkar.

7. Amir A. Rangkaian Ilmu Kedokteran Forensik (2nd ed). Medan: FK USU, 2010.

8. Gordon I, Shapiro HA, Berson SD. Forensic Medicine (a guide to principles) (3rd ed). Edinburgh: Churchill Livingstone, 1987. 